\title{
Hubungan efikasi diri dengan ketaatan minum Obat Anti Tuberkulosis (OAT) pada penderita tuberkulosis paru
}

\author{
U.C.A.S Isnainy ${ }^{1 *}$, Sri Sakinah², Heri Prasetya ${ }^{3}$
}

1Program DIII Keperawatan Universitas Malahayati Bandar Lampung. *Email: usastiawatycasi@gmail.com 2STIKES Muhammadiyah Sidrap

3Program Studi Ilmu Keperawatan, Fakultas Kedokteran , Universitas Malahayati Bandar Lampung.

\begin{abstract}
Self efficacy and treatment adherence of anti-TB drugs (ATD's) on patient with pulmonary tuberculosis
\end{abstract}

Background : Tuberculosis is a chronic disease with a long time treatment of 6 months or more, self-efficacy in patients is needed routinely to taking medicine which will achieve healing more over it can prevent the transmission of the disease. Patient should have self-efficacy, which is individual's belief in managing certain behaviors to achieve their healing. Adherence is the attitude of the patient to carrying out treatment methods and behaviors suggested by his doctor or medical care provider

Purpose : To determine the correlation between Self efficacy and treatment adherence of anti-TB drugs (ATD's) on patient with pulmonary tuberculosis

Method: The study was conducted in May-June 2019 using the Cross Sectional method. There were 36 respondents in Banjar Agung public health centre. Data collection was done by direct interview. The questionnaire was used the Self-Efficacy Questionnaire to assess self-efficacy levels and adherence questionnaire to assess respondent's medication adherence.

Results: Chi-Square analysis showed a significant correlation of self-efficacy and medication adherence to TB patients in Banjar Agung public health centre $(p=0,001)$.

Conclusion: There was a correlation of self-efficacy and medication adherence to TB patients in Banjar Agung public health Centre

\section{Keywords: Self efficacy; Treatment adherence; Anti-TB drugs (ATD's); Pulmonary tuberculosis}

Pendahuluan: Tuberkulosis adalah salah satu penyakit kronis dengan waktu pengobatan selama 6 bulan atau lebih, maka diperlukan adanya efikasi diri dalam diri pasien bahwa dengan rutin minum obat akan mencapai kesembuhan sehingga dapat mencegah penularan penyakit. Penderita harus memiliki efikasi diri, yaitu keyakinan individu dalam mengelola perilaku tertentu untuk mencapai kesembuhan. Kepatuhan adalah tingkat pasien melaksanakan cara pengobatan dan perilaku yang disarankan oleh dokternya ataupun petugas pelayan kesehatan..

Tujuan: Untuk mengetahui hubungan antara efikasi diri terhadap kepatuhan minum obat anti TB (OAT) di Puskesmas Rawat Inap Banjar Agung Kecamatan Jati Agung Kabupaten Lampung Selatan.

Metode: Penelitian dilakukan pada Mei-Juni 2019 dengan menggunakan metode Cross Sectional. Terdapat 36 responden di Puskesmas Rawat Inap Banjar Agung. Pengumpulan data dilakukan dengan cara wawancara langsung. Kuesioner yang digunakan adalah Kuisioner Efikasi Diri untuk menilai tingkat efikasi diri dan Kuisioner Ketaatan untuk menilai kepatuhan minum obat responden.

Hasil : Melalui analisis Chi-Square diperoleh nilai $p=0,001$ terhadap efikasi diri dengan kepatuhan minum obat pasien TB di Puskesmas Rawat Inap Banjar Agung

Simpulan: Terdapat hubungan yang bermakna antara efikasi diri dengan kepatuhan minum obat terhadap pasien TB di Puskesmas Rawat Inap Banjar Agung

Kata Kunci: Obat anti tuberkulosis; Ketaatan minum obat; Efikasi diri; Penderita; Tuberkulosis paru 
Hubungan efikasi diri dengan ketaatan minum Obat Anti Tuberkulosis (OAT) pada penderita tuberkulosis paru

\section{PENDAHULUAN}

Tuberculosis atau TB adalah penyakit radang parenkim paru karena infeksi kuman Mycobacterium tuberculosis. TB paru termasuk suatu pneumonia, yaitu pneumonia yang desebabkan oleh Mycobacterium tuberculosis. TB paru mencakup $80 \%$ dari keseluruhan kejadian penyakit TB, sedangkan $20 \%$ lainya merupakan TB ekstra pulmonar (Djojodibroto, 2014; Wiratma, 2016). TB sampai dengan saat ini masih merupakan salah satu masalah kesehatan masyarakat didunia walaupun upaya pengendalian dengan strategi DOTS (Directly Observed Treatment Short-Course) atau panduan obat anti tuberkulosis jangka pendek dan pengawasan menelan obat telah diterapkan dibanyak negara sejak tahun 1995 (Kementrian Kesehatan Republik Indonesia, 2014). Untuk di indonesia, pada tahun 2017 ditemukan jumlah kasus TB sebanyak 425.089 kasus, meningkat bila dibandingkan semua kasus TB yang ditemukan pada tahun 2016 yang sebesar 360.565 kasus. Jumlah kasus tertinggi yang dilaporkan terdapat di provinsi dengan jumlah penduduk yang besar yaitu Jawa Barat, Jawa Timur dan Jawa Tengah. Kasus TB di tiga provinsi tersebut sebesar $43 \%$ dari jumlah seluruh kasus TB di Indonesia (Kementerian Kesehatan Republik Indonesia, 2017).

Sedangkan di Provinsi Lampung tahun 2017, Jumlah penderita TB Paru BTA Positif sebanyak 5.612 penderita, dengan Cure rate $75,69 \%$ dan sembuh sebesar 93\%. Angka keberhasilan pengobatan sebesar 92,6\% (Dinas Kesehatan Provinsi Lampung, 2017). Di Kabupaten Lampung Selatan pada tahun 2017 jumlah seluruh kasus TB sebanyak 1.479 kasus meningkat dari tahun sebelumnya 1.272 kasus. Angka penemuan kasus TB BTA positif tahun 2017 sebesar 952 kasus (64\%) meningkat dari tahun sebelumnya sebesar 947 kasus (60\%). (Dinas Kesehatan Kabupaten Lampung Selatan, 2017). Untuk Jumlah cakupan penderita TB Paru di Puskesmas Rawat Inap Banjar Agung, dalam 5 tahun terakhir, jumlah cakupan temuan kasus TB Paru BTA Positif mengalami fluktuatif dengan kecendrungan peningkatan kasus, dari tahun 2013 sebanyak 38 kasus, turun menjadi 29 kasus di tahun 2014, 43 kasus di tahun 2015, 35 kasus ditahun 2016 dan tahun 2017. Adapun presentase keberhasilan ditahun 2017 adalah 87,5\% (Dinas Kesehatan Kabupaten Lampung Selatan, 2017).
Pengobatan TB yang merupakan Paket OAT (Obat Anti TBC) memerlukan waktu yang panjang, untuk kategori I (Pasien baru) Memerlukan waktu 6 bulan pengobatan, dan tambahan 3 bulan (Kategori II) untuk pasien yang masih dinyatakan positif (Relaps) setelah pengobatan 6 bulan pertama, dalam meminum obat harus sesuai aturan, sesuai waktu yang ditentukan dan tanpa putus yang bertujuan untuk mencegah terjadinya resistensi basil terhadap obat (Djojodibroto, 2014; Sari, Herman, Susyanty, \& Su'udi, 2018). Dengan panjangnya masa pengobatan, ketidak patuhan pasien terhadap pengobatan TB sering terjadi dan merupakan penyebab penting bagi gagal pengobatan dan relaps. Ketidak taatan pada pengobatan juga dapat berakibat pada timbulnya resistensi sehingga memerlukan pengobatan yang lebih lama dan lebih mahal serta rendahnya tingkat kesembuhan dibandingkan TB yang sensitif OAT (Puspasari, 2014; Zainaro \& Gunawan, 2019).

Dengan panjangnya masa pengobatan tersebut, salah satu faktor terpenting dalam keberhasilan proses pengobatan adalah adanya Self Efficacy atau kepercayaan diri yang tinggi dari diri pasien tersebut. Menurut Sarafino \& Smith (2011) hal yang paling terpenting yang harus dimiliki oleh individu untuk dapat melaksanakan perilaku sehat adalah self-efficacy (Sarafino \& Smith, 2014; Ariesti, 2018). Efikasi diri atau kemampuan diri dapat didefinisikan sebagai sejuah mana individu meyakini mereka kompeten untuk menghadapi tantangan dalam hidup (Neil, 2012; Khotimah, Radjah, \& Handarini, 2016).

Berdasarkan fenomena diatas maka peneliti tertarik untuk melakukan penelitian dengan judul " Hubungan Efikasi Diri Pasien TB Dengan Ketaatan Minum Obat Anti Tuberkulosis (OAT) di Puskesmas Rawat Inap Banjar Agung Kecamatan Jati Agung Lampung Selatan Tahun 2019".

\section{METODE PENELITIAN}

Jenis penelitian ini adalah kuantitatif yang bertujuan untuk mengetahui hubungan Efikasi diri dengan ketaatan minum Obat Anti Tuberkulosis (OAT) di wilayah kerja Puskesmas Rawat Inap Banjar Agung Kabupaten Lampung Selatan Tahun 2019. Penelitian ini menggunakan rancangan survey analitik dengan pendekatan Cross sectional. observasi atau pengumpulan data sekaligus pada suatu saat (point time approach).

\section{U.C.A.S Isnainy ${ }^{1 *}$, Sri Sakinah ${ }^{2}$, Heri Prasetya ${ }^{3}$}

'Program DIII Keperawatan Universitas Malahayati Bandar Lampung. *Email: usastiawatycasi@gmail.com ${ }^{2}$ STIKES Muhammadiyah Sidrap

${ }^{3}$ Program Studi llmu Keperawatan, Fakultas Kedokteran , Universitas Malahayati Bandar Lampung. 
Hubungan efikasi diri dengan ketaatan minum Obat Anti Tuberkulosis (OAT) pada penderita tuberkulosis paru

Populasi dalam penelitian ini adalah seluruh penderita TB Paru yang sedang menjalani pengobatan paket OAT sebanyak 36 orang. Subyek penelitian adalah pasien yang sedang menjalani proses pengobatan OAT. Dalam penelitian ini peneliti menggunakan metode total sampling. Waktu penelitian dilakukan bulan Mei hingga Juni 2019, setelah Surat Uji Laik Etik terbit pada tanggal 26 April 2019 dengan nomor 247/EC/KEPUNMAL///2019 . Yang menjadi variable independen dalam penelitian ini adalah Efikasi diri. Variabel dependen dalam penelitian ini adalah ketaatan minum obat OAT.

Untuk alat ukur pada penelitian ini, peneliti menggunakan instrumen berupa kuesioner $A$, yaitu kuisioner Efikasi Diri dengan jumlah pernyataan sebanyak 25 buah dengan menggunakan skala Likert, dimana jawaban responden hanya mencentang salah satu dari: SS (Sangat sesuai), S (Sesuai), TS (Tidak sesuai), STS (Sangat tidak sesuai). Skor minimum adalah 25 , dan skor maksimum adalah 100 . Efikasi diri baik jika skor $\geq 56$, dan efikasi diri buruk jika skor $<56$.Kuesioner B yaitu kuisioner Ketaatan dengan jumlah pernyataan sebanyak 10 buah menggunakan skala Guttman, dimana jawaban responden hanya terbatas 2 jawaban, Ya atau Tidak.Dikatakan taat jika skor $\geq 6$, dan tidak taat jika skor $<6$. Peneliti mengambil Kuesioner efikasi diri yaitu yang pernah diteliti oleh Alit Artha Sutrisna, tentang Hubungan Efikasi Diri Dengan Ketaatan Minum Obat Penderita TB tahun 2017 dengan hasil uji validitas dan reliabilitas Alpha (a) Cronbach`s sebesar 0.954 (Sutrisna, 2017).

HASIL

Tabel 1. Karakteristik Responden $\mathrm{N}=36$

\begin{tabular}{lcc}
\hline Variabel & Frekuensi (f) & Persentase (\%) \\
\hline Umur & & \\
$18-40$ th & 19 & 52.8 \\
$41-59$ th & 13 & 36.1 \\
$\geq 60$ th & 4 & 11.1 \\
Jenis Kelamin & & \\
Laki-laki & 24 & 66.7 \\
Perempuan & 12 & 33.3 \\
Pendidikan & & \\
Tidak Sekolah & 3 & 8.3 \\
SD & 6 & 16.7 \\
SMP & 19 & 52.8 \\
SMA & 7 & 19.4 \\
PT & 1 & 2,8 \\
Pekerjaan & & \\
Bekerja & 12 & 33.3 \\
Tidak Bekerja & 24 & 66.7 \\
Lama Pengobatan & & \\
Belum Lama (6-8 & & \\
bulan) & & 58.3 \\
Lama ( $\geq 8$ bln ) & 21 & 41.7 \\
Efikasi Diri & 15 & 69.4 \\
Baik & & 30.6 \\
Buruk & 25 & \\
Ketaatan Minum & 11 & \\
Obat Tuberkulosis & & \\
(OAT) & & \\
Taat & & \\
Tidak Taat & & \\
\hline
\end{tabular}

U.C.A.S Isnainy", Sri Sakinah ${ }^{2}$, Heri Prasetya ${ }^{3}$

'Program DIll Keperawatan Universitas Malahayati Bandar Lampung. *Email: usastiawatycasi@gmail.com ${ }^{2}$ STIKES Muhammadiyah Sidrap

${ }^{3}$ Program Studi llmu Keperawatan, Fakultas Kedokteran , Universitas Malahayati Bandar Lampung. 
Hubungan efikasi diri dengan ketaatan minum Obat Anti Tuberkulosis (OAT) pada penderita tuberkulosis paru

Karakteristik responden berdasarkan umur, jenis kelamin, pendidikan, bekerja/tidak bekerja dan lama pengobatan adalah dari faktor usia terbanyak adalah usia produktif dengan rentang 41-59 tahun sebesar 52,8\%. Dari jenis kelamin , Laki-laki mendominasi dengan jumlah $66,7 \%$. Pendidikan responden terbanyak mengenyam pendidikan SMP sebesar 52,8\%. Lama pengobatan responden terbanyak adalah penderita baru dengan lama pengobatan 2-4 bulan sebesar 58,3\%. Dan sebesar $66,7 \%$ penderita TB sudah tidak aktif lagi bekerja.

Lebih dari separuh responden yaitu $69,4 \%$ (25 orang) memiliki efikasi diri baik dan $(75 \%) 27$ responden taat dalam minum obat.

Tabel 2. Hubungan Efikasi Diri Dengan Ketaatan Minum Obat Anti Tuberkulosis (OAT)

\begin{tabular}{|c|c|c|c|c|c|c|c|c|}
\hline \multirow{3}{*}{ Efikasi Diri } & \multicolumn{4}{|c|}{ Ketaatan Minum Obat } & \multirow{2}{*}{\multicolumn{2}{|c|}{ Total }} & \multirow{3}{*}{$p$-value } & \multirow{3}{*}{$\begin{array}{c}\text { OR } \\
\text { (Cl 95\%) }\end{array}$} \\
\hline & \multicolumn{2}{|c|}{ Taat } & \multicolumn{2}{|c|}{ Tidak Taat } & & & & \\
\hline & $\mathbf{n}$ & $\%$ & $\mathrm{n}$ & $\%$ & $\mathbf{N}$ & $\%$ & & \\
\hline Baik & 23 & 63.9 & 2 & 5.5 & 25 & 69.4 & 0.001 & 20.125 (3.020- \\
\hline Buruk & 4 & 11.1 & 7 & 19.5 & 11 & 30.6 & & 134.090) \\
\hline Total & 27 & 75.0 & 9 & 25.0 & 36 & 100 & & \\
\hline
\end{tabular}

Berdasarkan tabel 2 dapat dijelaskan bahwa hubungan efikasi diri pasien TB Paru dengan ketaatan minum obat anti tuberkulosis (OAT) terdapat sebanyak 25 orang dari 36 orang responden $(69,4 \%)$ memiliki efikasi diri baik, diantaranya terdapat sebanyak 23 orang $(63,9 \%)$ orang responden taat dalam minum obat, dan 2 orang $(5,5 \%)$ orang responden tidak taat minum obat. Kemudian dari 11 efikasi diri buruk, diantaranya terdapat 4 orang $(11,1 \%)$ orang responden taat dalam minum obat dan 7 orang $(19,5 \%)$ orang responden tidak taat dalam minum obat. Hasil uji statistik diperoleh nilai $p$ value $=$ 0,001 lebih kecil dari nilai alpha 0,005 $(p<a)$ maka dapat disimpulkan adanya hubungan yang bermakna antara efikasi diri pasien TB Paru dengan ketaatan minum obat dalam mengikuti program pengobatan paket OA T.

Dari hasil analisis diperoleh $O R=20,125$ $(3.020-134,090)$ yang artinya responden dengan efikasi diri baik memiliki peluang 20 kali untuk taat dalam minum obat dibandingkan dengan efikasi buruk.

\section{PEMBAHASAN \\ Efikasi Diri}

Hasil penelitian menunjukkan bahwa dari 36 orang responden didapatkan $69,4 \%$ responden $(25$ orang) memiliki efikasi diri baik dan $11(30,6 \%)$ responden memiliki efikasi diri kurang baik. Dari penelitian yang dilakukan oleh Zainal dkk tentang faktor-faktor yang berpengaruh terhadap kepatuhan pengobatan TB di TB Care Aisyiyah
Kota Makassar, Efikasi diri (keyakinan atau kepercayaan, termasuk kesadaran) penderita TB untuk sembuh berpengaruh nyata pada kepatuhan pengobatan penderita TB (Muljono, Sugihen, \& Susanto, 2018). Efikasi diri (keyakinan atau kepercayaan, termasuk kesadaran) penderita TB untuk sembuh sangatlah baik sehingga mendorong penderita melakukan pengobatan secara teratur membuat penderita yakin, percaya dan mempunyai gambaran diri yang positif (Pribadi, Karyanto, \& Yansuri, 2019). Penderita juga memiliki optimisme yang baik dalam menjalani pengobatan walaupun terkadang mereka merasakan efek samping obat. Optimisme tersebut juga dipengaruhi oleh dorongan untuk bisa beraktivitas secara normal kembali dan dapat bekerja lagi untuk keluarganya (Muljono, Sugihen, \& Susanto, 2018; Ibrahim, Elliya, \& Pribadi, 2014).

Pengaruh dari efikasi diri pada proses kognitif seseorang sangat bervariasi. Pertama, efikasi diri yang kuat akan mempengaruhi tujuan pribadinya. Semakin kuat efikasi diri, semakin baik tujuan yang ditetapkan oleh individu bagi dirinya sendiri dan yang memperkuat adalah komitmen individu terhadap tujuan tersebut. Individu dengan efikasi diri yang kuat akan mempunyai cita-cita yang baik, mengatur rencana dan berkomitmen pada dirinya untuk mencapai tujuan tersebut. Kedua, individu dengan efikasi diri yang kuat akan mempengaruhi bagaimana individu tersebut menyiapkan langkahlangkah antisipasi bila usahanya yang pertama gagal dilakukan (Bandura, 2010).

U.C.A.S Isnainy ${ }^{1 *}$, Sri Sakinah ${ }^{2}$, Heri Prasetya ${ }^{3}$

'Program DIll Keperawatan Universitas Malahayati Bandar Lampung. *Email: usastiawatycasi@gmail.com ${ }^{2}$ STIKES Muhammadiyah Sidrap

${ }^{3}$ Program Studi llmu Keperawatan, Fakultas Kedokteran , Universitas Malahayati Bandar Lampung. 
Hubungan efikasi diri dengan ketaatan minum Obat Anti Tuberkulosis (OAT) pada penderita tuberkulosis paru

Ketaatan Minum Obat Anti Tuberkulosis (OAT)

Berdasarkan hasil penelitian didapati bahwa dari 36 orang responden didapatkan 27 orang $(54,5 \%)$ responden taat dalam minum obat dan 9 orang $(25 \%)$ responden tidak taat dalam minum obat. . istilah ketaatan (compliance atau adherence) didiskripsikan dengan sejauh mana pasien sesuai dengan ketentuan yang diberikan oleh profesional kesehatan (Arifin \& Ropyanto, 2016). Sedangkan menurut Notoatmojo (2012) Ketaatan berobat berasal dari kata 'patuh" yang berarti taat, suka menuruti dan disiplin (Muljono, Sugihen, \& Susanto, 2018). Terkait dengan terapi obat, ketaatan pasien didefinisikan sebagai derajat kesesuaian antara riwayat dosis yang sebenarnya dengan regimen dosis obat yang diresepkan. Dalam konteks pengendalian tuberkulosis paru atau TB paru, ketaatan terhadap pengobatan dapat didefinisikan sebagai tingkat ketaatan pasien pasien yang memiliki riwayat pengambilan obat terapeutik terhadap resep pengobatan (Pameswari, Halim, \& Yustika, 2016).

Menurut penelitian yang dilakukan oleh Lestari dan Chairil (2016), ketaatan minum obat anti tuberkulosis (OAT) dipengaruhi oleh beberapa faktor, antara lain : Motivasi ingin sembuh, Support dan dukungan keluarga, Pengawasan dari PMO , Penyuluhan / Pendidikan kesehatan, Tidak ingin terjadi penularan. (Lestari, \& Mustofa, 2016).

\section{Hubungan Efikasi Diri Dengan Ketaatan Minum Obat Anti Tuberkulosis (OAT)}

Terdapat sebanyak 25 dari 36 orang responden memiliki efikasi baik, diantaranya terdapat sebanyak $23(92,0 \%)$ orang responden taat dalam minum obat, dan $2(8,0 \%)$ orang responden tidak taat minum obat. Terdapat sebanyak 11 dari 36 orang memiliki efikasi diri kurang baik, diantaranya terdapat $4(36,4 \%)$ orang responden taat dalam minum obat, $7(63,6 \%)$ orang responden tidak taat dalam minum obat. Hasil uji statistik diperoleh nilai $p$ value $=0,001 \quad(p<a)$ maka dapat disimpulkan adanya hubungan yang bermakna antara efikasi diri pasien TB Paru dengan ketaatan minum obat anti tuberkulosis (OAT).

Hal ini membuktikan kebernaran tentang teori efikasi diri sebagaimana yang disebutkan Bandura bahwa pengaruh dari efikasi diri pada proses kognitif seseorang sangat bervariasi. Pertama, efikasi diri yang kuat akan mempengaruhi tujuan pribadinya. Semakin kuat efikasi diri, semakin baik tujuan yang ditetapkan oleh individu bagi dirinya sendiri dan yang memperkuat adalah komitmen individu terhadap tujuan tersebut. Individu dengan efikasi diri yang kuat akan mempunyai cita-cita yang baik, mengatur rencana dan berkomitmen pada dirinya untuk mencapai tujuan tersebut. Kedua, individu dengan efikasi diri yang kuat akan mempengaruhi bagaimana individu tersebut menyiapkan langkah-langkah antisipasi bila usahanya yang pertama gagal dilakukan (Bandura, 2010).

Pada penelitian ini dari 36 responden didapatkan 25 orang responden dengan efikasi diri baik namun terdapat 2 orang responden yang ternyata tidak taat dalam minum obat. Hal ini disebabkan oleh keterlupaan bagi pasien dalam minum obat dan kurangnya dukungan dari keluarga untuk mengingatkan dalam minum obat secara rutin, sehingga pasien tidak taat dalam minum obat serta faktor efek samping yang tak dapat diatasi oleh pasien/responden . Sementara itu didapati 11 orang responden memiliki efikasi diri kurang baik terdapat 4 orang responden yang ternyata taat dalam minum obat rutin pada pasien TB paru ini. Hal disebabkan oleh adanya dukungan dari keluarga untuk selalu mengingatkan untuk minum obat secara rutin setiap hari selama bulan, dukungan petugas kesehatan baik staf Puskesmas dan kader TB yang melakukan kunjungan dan memberi dukungan kepada responden untuk minum obat secara rutin selama 6 bulan lamanya.

\section{SIMPULAN}

Sebagian besar responden mempunyai efikasi diri kategori baik sebanyak $69,4 \%$ dan sebagian besar juga $(75 \%)$ responden taat dan mengikuti prosedur pengobatan Anti Tuberkulosis (OAT). Diketahui adanya hubungan yang bermakna antara efikasi diri pasien TB paru dengan ketaatan minum Obat Anti Tuberkulosis (OAT) di Puskesmas Rawat Inap Banjar Agung Kecamatan Jati Agung Lampung Selatan Tahun 2019.

\section{SARAN}

Hasil penelitian ini dapat dijadikan sebagai bahan masukan bagi Puskesmas setempat dalam menjalankan program pengobatan Obat Anti Tuberkulosis (OAT).

U.C.A.S Isnainy", Sri Sakinah ${ }^{2}$, Heri Prasetya ${ }^{3}$

'Program DIII Keperawatan Universitas Malahayati Bandar Lampung. *Email: usastiawatycasi@gmail.com ${ }^{2}$ STIKES Muhammadiyah Sidrap

${ }^{3}$ Program Studi llmu Keperawatan, Fakultas Kedokteran , Universitas Malahayati Bandar Lampung. 
Hubungan efikasi diri dengan ketaatan minum Obat Anti Tuberkulosis (OAT) pada penderita tuberkulosis paru

\section{DAFTAR PUSTAKA}

Ariesti, E. (2018). Peer Review: Hubungan SelfEfficacy Dengan Tingkat Kepatuhan Pengobatan Hipertensi Di Puskesmas Bareng Kota Malang.

Arifin, F. F., \& Ropyanto, C. B. (2016). Hubungan Antara Persepsi Tentang Penyakit Dengan Kepatuhan Minum Obat Hipoglikemik Oral (Oho) Di Puskesmas Srondol Kota Semarang (Doctoral dissertation, Diponegoro).

Bandura, A. (2010). Self efficacy. Diakses dari: (http://www.des.emory.edu/mfp/B anEncy.html.)

Dinas Kesehatan Kabupaten Lampung Selatan. (2017). Profil Kesehatan Kabupaten Lampung Selatan Tahun 2017. Dinkes Kabupaten Lampung Selatan

Dinas Kesehatan Kabupaten Lampung Selatan. (2017). Profil Kesehatan Puskesmas Rawat Inap Banjar Agung Kabupaten Lampung Selatan Tahun 2017. Dinkes Kabupaten Lampung Selatan

Dinas Kesehatan Provinsi Lampung. (2017). Profil Kesehatan Provinsi Lampung Tahun 2016.

Djojodibroto. D (2014). Respirologi , Penerbit Buku Kedokteran EGC

Ibrahim, F., Elliya, R., \& Pribadi, T. (2014). Hubungan Dukungan Keluarga Dengan Kepatuhan Minum Obat TB Paru Pada Penderita TB Paru Di Wilayah Kerja Puskesmas Panaragan Jaya Kabupaten Tulang Bawang Barat Tahun 2013. Holistik Jurnal Kesehatan, 8(2).

Kementerian Kesehatan Republik Indonesia. (2017). Profil Kesehatan Indonesia Tahun 2016. Jakarta

Kementrian Kesehatan Republik Indonesia. (2014). Pedoman Nasional Penanggulangan Tuberkulosis. Jakarta
Khotimah, R. H., Radjah, C. L., \& Handarini, D. M. (2016). Hubungan antara konsep diri akademik, efikasi diri akademik, harga diri dan prokrastinasi akademik pada siswa SMP negeri di kota malang. Jurnal Kajian Bimbingan dan Konseling, 1(2), 60-67.

Khotimah, R. H., Radjah, C. L., \& Handarini, D. M. (2016). Hubungan antara konsep diri akademik, efikasi diri akademik, harga diri dan prokrastinasi akademik pada siswa SMP negeri di kota malang. Jurnal Kajian Bimbingan dan Konseling, 1(2), 60-67.

Lestari, S., \& Mustofa, C. H. (2016). Faktor Yang Mempengaruhi Kepatuhan Penderita Tbc Untuk Minum Obat Anti Tuberkulosis (Factors contributing patiens' compliance with Anti Tuberculostatic Drug Therapy). MOTORIK Jurnal IImu Kesehatan (Journal Of Health Science), 1(2).

Muljono, P., Sugihen, B. G., \& Susanto, D. (2018). Faktor-faktor Yang Berpengaruh Terhadap Kepatuhan Pengobatan Penderita Tb Pada Program "Community Tb Care" Aisyiyah Kota Makassar. Jurnal Penelitian Komunikasi dan Pembangunan, 19(2), 129-142.

Neil, N. (2012). Psikologi Kesehatan. Pengantar untuk perawat dan profesional kesehatan lain. Jakarta EGC.

Notoatmodjo, S. (2012). Promosi kesehatan dan perilaku kesehatan. Jakarta: rineka cipta, 4562.

Pameswari, P., Halim, A., \& Yustika, L. (2016). Tingkat Kepatuhan Penggunaan Obat pada Pasien Tuberkulosis di Rumah Sakit Mayjen H. A Thalib Kabupaten Kerinci. Jurnal Sains Farmasi \& Klinis, 2(2), 116-121.

Pribadi, T., Karyanto, K., \& Yansuri, Y. (2019). Hubungan gambaran diri dalam berinteraksi sosial pada penderita TB paru di wilayah kerja UPT Puskesmas Negeri Agung LampungIndonesia. Holistik Jurnal Kesehatan, 13(2), 184-193.

U.C.A.S lsnainy", Sri Sakinah ${ }^{2}$, Heri Prasetya ${ }^{3}$

'Program DIII Keperawatan Universitas Malahayati Bandar Lampung. *Email: usastiawatycasi@gmail.com

${ }^{2}$ STIKES Muhammadiyah Sidrap

${ }^{3}$ Program Studi llmu Keperawatan, Fakultas Kedokteran , Universitas Malahayati Bandar Lampung. 
Hubungan efikasi diri dengan ketaatan minum Obat Anti Tuberkulosis (OAT) pada penderita tuberkulosis paru

Puspasari,N.(2014). Karakteristik Pasien Tuberkulosis yang Memperoleh Pengobatan Kategori 2 di Pengobatan Penyakit Paru-paru (UP4) Provinsi Kalimantan Barat Tahun 20092012

Sarafino, E. P., \& Smith, T. W. (2014). Health psychology: Biopsychosocial interactions. John Wiley \& Sons.

Sari, I. D., Herman, M. J., Susyanty, A. L., \& Su'udi, A. (2018). Analisis Biaya Tuberkulosis Paru Kategori Satu Pasien Dewasa di Rumah Sakit di DKI Jakarta. Jurnal Kefarmasian Indonesia, 8(1), 44-54.
Sutrisna, A. A. (2017). Hubungan Efikasi Diri Dengan Kepatuhan Minum Obat Penderita Tuberkulosis Paru di Rumah Sakit Paru Respira Yogyakarta (Doctoral dissertation, STIKES Jenderal Achmad Yani Yogyakarta).

Wiratma, D. Y. (2016). Pengaruh perbedaan metode pemeriksaan laju endap darah (led) terhadap nilai led pasien tersangka penderita tuberkulosis paru di UPT. Kesehatan paru masyarakat dinas kesehatan Provinsi Sumatera Utara Medan Tahun 2015. Jurnal Analis Laboratorium Medik, 1(1), 24-31.

Zainaro, M. A., \& Gunawan, A. (2019). Kualitas pelayanan kesehatan rawat jalan dengan tingkat kepatuhan minum obat penderita tuberkulosis paru. Holistik Jurnal Kesehatan, 13(4), 381-388. 